\title{
Characteristics of fruits and seeds of Cereus plants (Cactaceae) grown in South and Northeastern Brazil
}

\begin{abstract}
The physical and physiological characteristics of fruits and seeds were analyzed so that parameters may be determined to differentiate cactus plants of the Cereus genus from south and northeastern Brazil. Length, width, bark thickness, pulp diameter, weight of fruits, and sugar content ( ${ }^{\circ}$ Brix) of the fruit pulp, number of seeds (NS), weight of 100 seeds $\left(\mathrm{P}_{100}\right)$ and germination taxa $(\% \mathrm{G})$ of the seeds from plants of the two regions were evaluated. Fruit length, bark thickness and Brix degree were higher in Cereus plants from Maringá (south) than in plants from Picos (northeast), whilst the $\mathrm{P}_{100}$ of plants cultivated in Picos was higher than the $\mathrm{P}_{100}$ of plants grown in Maringá. NS and $\% \mathrm{G}$, at $30^{\circ} \mathrm{C}$, were not significantly different in the seeds of the plants cultivated in Maringá and Picos. Positive Pearson correlation was reported between NS and the fruits' weight, length, width, and diameter. Fruit width had a positive correlation with the weight, length, diameter, bark thickness and sugar content. The length, diameter and thickness of the bark were also positively correlated with the fruits' sugar content. Above evidences suggest that larger fruits present higher Brix degree. The present study was important to shown that the Cereus plants from Maringá may be a source of bigger and sweeter fruits, essential characteristics for breeding programs..
\end{abstract}

Keywords: cactus, mandacaru, fruit length, bark thickness, fruit weight, weight of seeds, germination rate

\section{Introduction}

Some studies have revealed the importance of the cactus species Cereus peruvianus Mill. as a fruit-crop in Israel. ${ }^{1-3} \mathrm{~A}$ program of domestication and selection of plants of $C$. peruvianus initiated in the 90's of the last century led to the current production of the fruits that have been commercialized mainly in Israel with the name "Koubo". Orchard of C. peruvianus in Qetura (southern Arava Valley, Israel) was originally established with seeds collected from various private garden in Southern California. Years later, seeds of $C$. jamacaru collected from the semi-arid zones of Brazil, known there by the local name mandacaru, were introduced in semi-arid ecozones in Israel ${ }^{3,5}$ and crosses between the two species showed that the two can pollinate each other and produce viable seedlings. ${ }^{5}$

Crosses between the two species is not necessarily an indication that the two are the same species. However, the compatibility between plants from different regions is an important strategy for breeding programs. Species characteristics, genetics and breeding, propagation and fruits development, ripening and postharvest behavior were reported by Mizhari. ${ }^{4}$

Molecular analysis of various genotypes by Gutman et al..$^{5}$ showed that $C$. peruvianus species has a narrow genetic base and that additional germplasms are required for further efficient fruit improvement. Additional germplasms from Cereus species from south and northeast Brazil may be an alternative to expand the genetic base of the breeding program in Qetura.The C. jamacaru species represents a wild natural resource in the semiarid region of northeastern Brazil that has been mainly used as forage for ruminants, such as dairy cattle, sheep, ${ }^{6}$ goats ${ }^{7,8}$ and calves. ${ }^{9}$ Medicinal importance has also been attributed to $C$. jamacaru since the phenolic and alkaloid compounds extracted from the plant cladodes are related to antioxidant activity and may act on the cell cycle of the tumor cells, both in vitro and in vivo, with anticancer effects and tumor reduction. ${ }^{10}$ While the $C$. jamacaru species represents a wild natural resource in the semiarid region of northeastern Brazil, the C. peruvianus referred as synonym to $C$. hildmannianus ${ }^{11}$ is extensively used as ornamental plants in home gardens and public parks and squares. Further, an industrial
Volume 4 Issue 5 - 2020

\author{
Gilberto Codignole Luz,' Hugo Zeni Neto, ${ }^{2}$ \\ Claudete Aparecida Mangolin, ${ }^{3}$ Maria de \\ Fátima PS Machado 3 \\ 'Graduate student in Agronomy, Universidade Estadual de \\ Maringá, Brazil \\ 2Department of Agronomy, Universidade Estadual de Maringá, \\ Brazil \\ ${ }^{3}$ Department of Biotechnology, Genetics and Cell Biology, \\ Universidade Estadual de Maringá, Brazil \\ Correspondence: Maria de Fátima PS Machado, Department \\ of Biotechnology, Genetics and Cell Biology, Universidade \\ Estadual de Maringá, Brazil, Tel 55+(44) 30 I 4468I, \\ Emailmfpsmachado@uem.br
}

Received: September 18, 2020 | Published: October 05, 2020 and economic importance has been attributed to the C.peruvianus in south Brazil. In fact, C. peruvianus plants are used for the extraction of gum used in cosmetic and food industries ${ }^{12}$ and for the retrieval of complex heteropolysaccharides used in purification processes for industrial waste water. ${ }^{13}$ Medicinal importance is also attributed to C. peruvianus. Arabinogalactan, extracted from the gum, has been indicated for the treatment of gastric ulcers. ${ }^{14}$

The economic importance of C. jamacaru plants in Brazil's northeastern region has stimulated studies to assess the viability, chemical composition and potential for seed germination of the species. ${ }^{15-20}$ However, there are no reports of studies with fruits and seeds of the $C$. peruvianus species cultivated in south Brazil; only the effect of different temperatures on seeds germination was reported by Bevilaqua et al. ${ }^{18}$ The objective of the current study was to verify if fruits and seeds of Cereus from a location in the northeast and a location in the south regions of Brazil present promising characteristics for programs of breeding.

\section{Materials and methods}

Fruits of Cereus were collected from six and three plants cultivated in South (Maringá, PR, Brazil) and Northeastern (Picos, PI, Brazil), respectively. The mature fruits were collected in plants found in public parks, home gardens, and open fields in urban areas. The primary source of each plant is unknown since the vegetative propagation is the predominant form of multiplication for the species of Cereus, but there is a great chance of they have been propagated from different plants (inference made from different place of collect and personal information). Nine fruits, representing the northeastern region (3 fruits/plant), were collected in Picos $\left(07^{\circ} 04^{\prime} 37^{\prime \prime} \mathrm{S} ; 41^{\circ} 28^{\prime} 01^{\prime \prime} \mathrm{W}\right)$ and thirty (4-10 fruits/plant), representing the south region, were collected in Maringá (2325'38'S $\left.51^{\circ} 56^{\prime} 15^{\prime \prime} \mathrm{W}\right)$. The soil of the region in Picos is clayey with litholics and quartz sand and characterizes Cerrado/ Savanah vegetation. The climate is characterized as tropical semiarid and hot, with maximum temperature $39^{\circ} \mathrm{C}$, minimum temperature $22^{\circ} \mathrm{C}$, and an average annual temperature of $30^{\circ} \mathrm{C}$. Rains are scarce and the driest period occurs throughout seven to eight months. The soil of the region in Maringá consists of dystrophic red Latosol, with 
subtropical temperate climate. Mean annual temperature is $21.95^{\circ} \mathrm{C}$; minimum temperature is $10.3^{\circ} \mathrm{C}$; and maximum temperature is $33.6^{\circ} \mathrm{C}$. Rainfall rate is at its minimum in March, June, July and August and at its maximum in November, December and January, with a mean annual rainfall of $1,500 \mathrm{~mm}$. Mean relative humidity is $66 \%$.

Length, width, bark thickness, pulp diameter, weight and the sugar content $\left({ }^{\circ}\right.$ Brix; one-degree Brix is $1.0 \mathrm{~g}$ of sucrose in $100 \mathrm{~g}$ of solution) were evaluated in the fruits of the plants from the two regions. A digital caliper was used to measure fruits' length, width, bark thickness and pulp diameter. A refractometer was employed to measure ${ }^{\circ}$ Brix (soon after collection). After the measurement of the fruits, the seeds were excised out of the mature fruit and washed in tap and distilled water to remove any remaining mucilage. Seeds were then surface sterilized with $10 \%$ sodium hypochlorite for $5 \mathrm{~min}$ and washed in distilled water. After drying at room temperature, the seeds of each fruit were counted to estimate the number of seeds per fruit (NS). One hundred seeds of each fruit were weighed in an analytical balance (SHIMADZU AUY 220) to estimate weight of 100 seeds $\left(\mathrm{P}_{100}\right)$.

Seed germination was done following Bevilaqua et al. ${ }^{18}$ Seeds were first soaked in sterilized water for $24 \mathrm{~h}$ according to recommendations by Carvalho et al. ${ }^{21}$ distributed on two sheets of Germitest ${ }^{\circledR}$ type paper moistened with distilled water and packed in plastic Petri dishes. ${ }^{18}$ Twenty seeds per plastic Petri dish were used in replicates, with five replicates of seeds obtained from fruits of Maringá and from fruits of Picos, totaling 100 seeds from each region. The experiment was carried out in a germination chamber at $30^{\circ} \mathrm{C}$, using a $16 \mathrm{~h}$-photoperiod. Germination counts were taken daily, with final counts after 10 days. Seed with an emerged radicle was considered germinated.

Statistical software $\mathrm{R}^{22}$ was employed to test whether length, width, bark thickness, pulp diameter, weight and sugar content $\left({ }^{\circ}\right.$ Brix $)$ of the pulp in the fruits, and $\mathrm{NS}, \mathrm{P}_{100}$, and germination taxa $(\% \mathrm{G})$ of the seeds from plants of the two regions were significantly different.

\section{Results and discussion}

\section{Characteristics of the Cereus fruits of plants grown in Maringá and Picos}

Fruit length, bark thickness and ${ }^{\circ}$ Brix were higher in Cereus plants from Maringá (south) than in plants from Picos (northeast), while fruit width, diameter and weight were not significantly different for the two regions (Table 1). In spite of the greater length and thickness of the bark of the fruits from Maringá, the weight of the fruits was not greater than the weight of the fruits from Picos. The fruit length of Picos varied from 59.6 to $123 \mathrm{~mm}$, with an average $83.6 \mathrm{~mm}$, similar to the average described by Abud et al. ${ }^{23}$ for fruits of $C$. jamacaru $(82.36 \pm 5.78 \mathrm{~mm}$ in length). Mean weight of the Picos fruits in current study $(153 \mathrm{~g})$ was also similar to the fruit weight reported by Abud et al. ${ }^{23}$ for fruits of $C$. jamacaru $(154.66 \pm 40.01 \mathrm{~g})$. On the other hand, the diameter of the fruits from Picos evaluated in current study $(42.8$ g) was smaller than the diameter described for fruits of $C$. jamacaru $62.63 \pm 6.63 \mathrm{~mm}^{23}$

Table I Variance analysis of fruit width (FWi), fruit diameter (FØ), bark thickness (BT), fruit length (FL), sugar content $\left({ }^{\circ}\right.$ Brix) and fruit weight (FWe) evaluated in fruits of plants of the genus Cereus (Cactaceae) cultivated in south (Maringá, PR) and in northeastern (Picos, PI) Brazil

\begin{tabular}{|c|c|c|c|c|c|c|c|c|c|c|c|c|}
\hline Parameters & $\begin{array}{l}\text { FWi } \\
\text { Maringá }\end{array}$ & Picos & $\begin{array}{l}\text { FØ } \\
\text { Maringá }\end{array}$ & Picos & $\begin{array}{l}\text { BT } \\
\text { Maringá }\end{array}$ & Picos & $\begin{array}{l}\text { FL } \\
\text { Maringá }\end{array}$ & Picos & $\begin{array}{l}{ }^{\circ} \text { Brix } \\
\text { Maringá }\end{array}$ & Picos & $\begin{array}{l}\text { FWe } \\
\text { Maringá }\end{array}$ & Picos \\
\hline minimum & 37.9 & 43 & 31 & 33.3 & 3 & 3.1 & 66 & 59.6 & 8.1 & 6.1 & 45.4 & 62.2 \\
\hline maximum & 80 & 78.2 & 72 & 64.8 & 10 & 6.32 & 126 & 123 & 17.1 & 10.8 & 400 & 344 \\
\hline${ }^{\prime} \hat{\mu}$ & $60.9 a$ & $57.0 \mathrm{a}$ & $47.9 \mathrm{a}$ & $42.8 \mathrm{a}$ & $6.33 a$ & $5.06 \mathrm{~b}$ & $98.2 \mathrm{a}$ & $83.6 \mathrm{~b}$ & $12.6 \mathrm{a}$ & $8.84 b$ & $199 a$ & $153 a$ \\
\hline${ }^{2} \hat{\sigma}^{2}$ & I47NS & 198NS & I33NS & I3INS & $2.92 \mathrm{NS}$ & $1.14 \mathrm{NS}$ & $209 N S$ & $469 N S$ & $6.33 \mathrm{NS}$ & $2.39 \mathrm{NS}$ & $6200 N S$ & 10705 NS \\
\hline$\hat{\sigma}$ & 12.12 & 14.07 & 11.53 & 11.44 & 1.7 & 1.06 & 14.45 & 21.65 & 2.51 & 1.54 & 78.74 & 103.46 \\
\hline${ }^{3} \mathrm{~W}$ & 0.04468 & 0.1855 & 0.752 & 0.189 & 0.5177 & 0.2544 & 0.2145 & 0.993 & 0.7406 & 0.2737 & 0.03329 & 0.4788 \\
\hline
\end{tabular}

'Equal horizontal letters do not differ statistically from one another by $\mathrm{t}$ test at $5 \%$ probability. ${ }^{2} *$ or ${ }^{\mathrm{Ns}}$ by $\mathrm{F}$ test at $5 \%$ probability. ${ }^{3}$ Statistic calculated by the Shapiro-Wilks test.

Variation in ${ }^{\circ}$ Brix $(8.1-17.1)$ and mean value (12.6) were higher in Cereus fruits cultivated in Maringá than in fruits cultivated in Picos (Table 2). The maximum value of ${ }^{\circ}$ Brix observed in fruits from Picos (10.8) is similar to the mean value for C. jamacaru. Silva et al. ${ }^{24}$ has reported mean rate of $10.13{ }^{\circ}$ Brix for fruit pulp of C. jamacaru. Although few studies on fruits of the Cereus species

Table 2 Analysis of variance of number of seeds $(\mathrm{Ns})$, weight of 100 seeds $\left(\mathrm{P}_{100}\right)$ and percentage of germination $(\% \mathrm{G})$ evaluated in seeds of plants of the genus Cereus (Cactaceae) cultivated in south (Maringá, PR) and northeastern (Picos, Pl) Brazil

\begin{tabular}{lllllll}
\hline & Ns & \multicolumn{3}{c}{ P I00 $(\mathbf{g})$} & \multicolumn{2}{c}{ Germination (\%) } \\
\cline { 2 - 7 } Parameters & Maringá & Picos & Maringá & Picos & Maringá & Picos \\
\hline Minimum & 65 & 140 & 0.196 & 0.234 & 67 & 71.7 \\
Maximum & 2775 & 1878 & 0.446 & 0.494 & 97 & 98 \\
${ }^{1} \hat{\mu}$ & $1383 \mathrm{a}$ & $803 \mathrm{a}$ & $0.301 \mathrm{~b}$ & $0.366 \mathrm{a}$ & $81.6 \mathrm{a}$ & $84.5 \mathrm{a}$ \\
${ }^{2} \hat{\sigma}^{2}$ & $690265 \mathrm{NS}$ & $49694 \mathrm{INS}$ & $0.00396 \mathrm{NS}$ & $0.00602 \mathrm{NS}$ & $71.8 \mathrm{NS}$ & $88.0 \mathrm{NS}$ \\
$\hat{\sigma}$ & 830.82 & 704.94 & 0.06 & 0.07 & 8.47 & 9.38 \\
${ }^{3} \mathrm{~W}$ & 0.1075 & 0.5 & 0.6427 & 0.08393 & 0.4763 & 0.3496 \\
\hline
\end{tabular}

'Equal horizontal letters do not differ statistically from one another by $\mathrm{t}$ test at $5 \%$ probability. ${ }^{2} *$ or NS by $\mathrm{F}$ test at $5 \%$ probability. ${ }^{3}$ Statistic calculated by Shapiro-Wilks test.

Citation: Luz GC, Neto HZ, Mangolin CA, et al. Characteristics of fruits and seeds of Cereus plants (Cactaceae) grown in South and Northeastern Brazil. Horticult Int J. 2020;4(5): I8I-I85. DOI: I0.15406/hij.2020.04.00I80 


\section{Number, weight and germination rate of Cereus seeds grown in Maringá and Picos}

The number of seeds and the germination rate at $30^{\circ} \mathrm{C}$ were not significantly different in the seeds of the plants cultivated in Maringá and Picos (Table 2) while the weight of 100 seeds $\left(\mathrm{P}_{100}\right)$ of the plants cultivated in Picos was higher than the $\mathrm{P}_{100}$ of the plants grown in Maringá. Heavier seeds in cacti have been associated with cultivated plants. Rojas-Aréchiga et al. ${ }^{25}$ evaluated the weight and the germination rate of seeds of cultivated and wild populations of the columnar species Stenocereus stellatus and found that seed weight and germination rate were higher in cultivated populations. Researchers suggested that human intervention for the cultivation of this species has favored seed vigor and germination capacity in the cultivated plants. Although the germination rate was not different in the Maringá and Picos seeds, the higher weight of the Picos seeds may be due to a more intensive cultivation of $C$. jamacaru plants, which has been mainly used for forage to ruminants, such as dairy cattle ${ }^{6}$ and calves. ${ }^{9}$

On the other hand, significant differences in seed weights from the Picos and Maringá (lower $\mathrm{P}_{100}$ values detected in seeds of Maringá) indicate smaller seed size. As seed size may be a parameter to differentiate species, the smaller size of the seeds in fruits collected from plants in Maringá may indicate the occurrence of different species of Cereus in the two Brazilian states, according to the premise of our study: C. jamacaru in northeastern Brazil and the C. peruvianus synonym of $C$. hildmannianus in south Brazil.

The relationship between seed mass with germination rate has not been observed in 17 cacti species (Cereus hankeanus, Cleistocactus baumannii, Echinopsis aurea, E. leucanta, E. candicans, E. spiniflora, Gymnocalycium bruchii, G. capillense, G. castellanosii, G. monvillei, G. mostii, G. quehlianum, G. schickendantzii, G. stellatum, Harrisia pomanensis, Parody mammulosa and Stetsonia coryne) of seven different genera from the central region of Argentina. ${ }^{26}$ These researchers only observed that the heavier seed generated larger seedlings.

Although there is evidence in another species of cactus (Gymnocalycium monvillei) that the characteristics of the germination differ according to the distribution of the plants at different altitudes, ${ }^{27}$ differences in the germination rates of the seeds of Cereus plants Maringá and Picos were not detected in current study nor were they observed in a study by Bevilaqua et al. ${ }^{18}$ No significant differences were observed, at $25^{\circ} \mathrm{C}$ and $30^{\circ} \mathrm{C}$, in the germination rate of the seeds of the two regions. Over a period of four days, the germination rate of seeds maintained at $30^{\circ} \mathrm{C}$ was greater than the germination rate of seeds maintained at $25^{\circ} \mathrm{C}$. However, after 8 days, temperatures $25^{\circ} \mathrm{C}$ and $30^{\circ} \mathrm{C}$ were equally effective for the germination of the plants from Maringá and Picos. Temperatures 25 and $30^{\circ} \mathrm{C}$ were also the most appropriate conditions for the germination of Cereus jamacaru seeds described by Alencar et al. ${ }^{17}$ Guedes et al. ${ }^{16}$ and Meiado et al. ${ }^{28}$ reported that the optimal temperature for germination of $C$. jamacaru seeds was $30^{\circ} \mathrm{C}$, whereas studies by Alencar et al. ${ }^{17}$ showed that the germination of C. jamacaru seeds was higher $20^{\circ} \mathrm{C}$ and $25^{\circ} \mathrm{C}$. Evidence that $25^{\circ} \mathrm{C}$ is an adequate temperature for the germination of $C$. jamacaru seeds contradicts the observation that temperatures below $30^{\circ} \mathrm{C}$ were not adequate for the germination of $C$. jamacaru seeds ${ }^{16}$. Abud et al. ${ }^{23}$ also revealed that the highest percentage of germination in $C$. jamacaru seeds $(89 \%)$ occurred at $25^{\circ} \mathrm{C}$.

In current study, maximum germination rate of Cereus plants from Picos reached $98 \%$, close to rates by Meiado et al..$^{28}$ for C. jamacaru seeds $(95.8 \%)$ and for in vitro germination of C. jamacaru $(92.6 \%)$ seeds described by Correia et al. ${ }^{29} \mathrm{~A}$ lower germination rate for Cereus seeds from Picos (85.3\%) was reported by Bevilaqua et al. ${ }^{18}$ However, the above was not considered significantly different from the seed germination rate of Maringá (92.7\%).

\section{Pearson correlation coefficients for fruits' and seeds' characteristics of Cereus plants from Picos and Maringá}

Pearson correlation coefficients for the characteristics of the fruits and seeds of Cereus plants grown in Maringá and Picos are shown in Table 3. A positive correlation was observed between the number of seeds and the weight, length, width, and diameter of the fruits. Fruit width showed positive correlation with weight, length, diameter, bark thickness and sugar content ( ${ }^{\circ}$ Brix). The bark's length, diameter and thickness were also positively correlated with the fruits' ${ }^{\circ}$ Brix. Evidences suggest that larger fruits present higher sugar content.

Table 3 Pearson correlation coefficients for the characteristics of the seeds and fruits: number of seeds (Ns), weight of 100 seeds $\left(\mathrm{P}_{100}\right)$ and percentage of germination $(\% \mathrm{G})$ in seeds, and fruit width (FWi), fruit diameter (FØ), bark thickness (BT), fruit length (FL), sugar content ( ${ }^{\circ}$ Brix) and fruit weight (FWe) evaluated in plants of the genus Cereus (Cactaceae) cultivated in south (Maringá, PR) and in northeastern (Picos, PI) Brazil

\begin{tabular}{|c|c|c|}
\hline Variables & Pearson coefficients & p-value \\
\hline Ns $\times \mathrm{PIO0}$ & $-0.61134509 * *$ & 0.0000356 \\
\hline Ns $\times \mathrm{FWi}$ & $0.66|447| 3^{* *}$ & 0.000004529 \\
\hline Ns $\times F \varnothing$ & $0.56876478 * *$ & 0.00015817 \\
\hline Ns $\times B T$ & $0.22077467 \mathrm{NS}$ & 0.1768192 \\
\hline Ns $\times F L$ & $0.71616692 * *$ & $2.957202 \times 10-^{7}$ \\
\hline Ns $\times$ Brix & $0.24875232 \mathrm{NS}$ & 0.1267532 \\
\hline $\mathrm{Ns} \times \mathrm{FWe}$ & $0.74003444^{* *}$ & $7.296901 \times 10^{8}$ \\
\hline Ns $\times \% G$ & $0.07156310 \mathrm{NS}$ & 0.665068 \\
\hline $\mathrm{PIO0} \times \mathrm{FWi}$ & $-0.2866968 \mathrm{INS}$ & 0.07680627 \\
\hline PI00x FØ & $-0.18903039 N S$ & 0.2491101 \\
\hline PI00x BT & $-0.15959592 \mathrm{NS}$ & 0.3318032 \\
\hline $\mathrm{PI} 100 \times \mathrm{FL}$ & -0.4198596 INS & 0.007792421 \\
\hline PI00x Brix & $-0.11308070 \mathrm{NS}$ & $0.49308 \mid 4$ \\
\hline PI00x FWe & $-0.29584063 N S$ & $0.06746|4|$ \\
\hline PI00x \%G & $0.024 I 7807 N S$ & 0.883842 \\
\hline$L F \times F \varnothing$ & $0.87866382 * *$ & $1.94 \times 10-13$ \\
\hline$L F \times B T$ & $0.32429196 *$ & 0.04399803 \\
\hline$L F \times F L$ & $0.48181346 *$ & 0.001898259 \\
\hline LF $x$ Brix & $0.33100901 *$ & 0.03955928 \\
\hline $\mathrm{LF} \times \mathrm{FWe}$ & $0.82336789 * *$ & $1.233469 \times 10-10$ \\
\hline$L F \times \% G$ & $-0.16792242 \mathrm{NS}$ & 0.3068591 \\
\hline$\varnothing \mathrm{F} \times \mathrm{BT}$ & $0.23001892 \mathrm{NS}$ & 0.1589233 \\
\hline$\varnothing \mathrm{F} \times \mathrm{FL}$ & $0.4326 \mathrm{I} 245 \mathrm{NS}$ & 0.005948716 \\
\hline$\varnothing \mathrm{F} \times$ Brix & $0.49161340^{*}$ & $0.00148106 \mid$ \\
\hline$\varnothing \mathrm{F} \times \mathrm{FWe}$ & $0.81067458^{* *}$ & $3.970411 \times 10-10$ \\
\hline$\varnothing \mathrm{F} \times \% \mathrm{G}$ & $-0.27744705 \mathrm{NS}$ & 0.087259 \\
\hline $\mathrm{EC} \times \mathrm{FL}$ & $0.13458895 \mathrm{NS}$ & 0.4139925 \\
\hline EC $\times$ Brix & $0.35152467^{*}$ & 0.02820567 \\
\hline $\mathrm{EC} \times \mathrm{FWe}$ & $0.206582 \mathrm{IINS}$ & 0.207023 \\
\hline $\mathrm{EC} \times \% \mathrm{G}$ & $0.04540868 \mathrm{NS}$ & 0.7837063 \\
\hline$C F \times$ Brix & $0.37825535^{*}$ & 0.01758137 \\
\hline $\mathrm{CF} \times \mathrm{FWe}$ & $0.79874865^{* *}$ & $1.102813 \times 10-9$ \\
\hline $\mathrm{CF} \times \% \mathrm{G}$ & $0.07868946 \mathrm{NS}$ & 0.6339557 \\
\hline $\mathrm{PF} \times \% \mathrm{G}$ & -0.0996792 INS & 0.5460099 \\
\hline Brix $x$ FWe & 0.44458674 NS & 0.004573569 \\
\hline Brix $\times \% G$ & $-0.15229045 \mathrm{NS}$ & 0.354693 \\
\hline
\end{tabular}


On the other hand, seed weight and germination rate failed to correlate with fruit characteristics. Evidences that fruit and seed characteristics do not influence seed germination were also described in other species of cacti (Aylostera narvaecensis, A. buiningiana, Rebutia kupperiana var. spiniflorum, and $R$. donaldiana) by Mihalte et al. ${ }^{30}$

Among the characteristics of seeds (NS, $\mathrm{P}_{100}$, and $\% \mathrm{G}$ ) and fruits (length, width, diameter, bark thickness, weight and ${ }^{\circ} \mathrm{Brix}$ ) of Cereus from Maringá and Picos analyzed in the present study, the $\mathrm{P}_{100}$, length of fruits, bark thickness and ${ }^{\circ}$ Brix may be recommended to discriminate plants from the two regions: $\mathrm{P}_{100}$ rate was higher in Picos, while fruit length, bark thickness and ${ }^{\circ}$ Brix were higher in the fruits from Maringá. The polymorphism of the lipase-5 locus ${ }^{18}$ and polymorphisms of DNA fragments obtained with restriction enzymes and amplified by polymerase chain reaction (AFLP) ${ }^{31}$ also indicated low genetic identity and high genetic divergence, respectively, between the Maringá and Picos plants, while the simple sequence repeats loci of DNA (SSR loci) ${ }^{32}$ indicated moderate genetic divergence. Consequently, the analysis of morphological and physiological characteristics of fruits and seeds, plus biochemical and molecular characteristics of Cereus plants cultivated in Maringá and Picos, demonstrated that only $46 \%$ of these characteristics may discriminate plants from the two contrasting regions of south and northeastern Brazil.

Although few characteristics may be employed to distinguish and/or specify plants of Cereus from south and northeastern Brazil, current analysis was important to verify that the plants of Maringá may be source of bigger and sweeter fruits, essential characteristics for the breeding program of Cereus peruvianus as fruit crop in Israel which has a program of domestication and selection of plants of $C$. peruvianus initiated in the 90's of the last century and is interested in introducing material from Brazil.

\section{Conclusion}

The weight of 100 seeds $\left(\mathrm{P}_{100}\right)$, fruit length, bark thickness and ${ }^{\circ}$ Brix may be recommended to discriminate plants from Maringá (south Brazil) and Picos (northeast Brazil): $\mathrm{P}_{100}$ was higher in Picos, whereas fruit length, bark thickness and ${ }^{\circ}$ Brix were higher in fruits from Maringá. Therefore, plants from Maringá may be source of bigger and sweeter fruits, essential characteristics for the breeding program of Cereus peruvianus.

\section{Acknowledgments}

The authors would like to thank the Coordination for the Upgrading of Higher Education Personnel (Coordenação de Aperfeiçoamento de Pessoal de Nível Superior - CAPES) Finance code 001.

\section{Conflicts of interest}

Authors declare no conflict of interest exists.

\section{References}

1. Nerd A, Raveh E, Mizrahi Y. Adaptation of five columnar cactus species to various condictions in the Negev Desert of Israel. Economic Botany. 1993; 47(3):304-311.

2. Weiss J, Nerd A, Mizrahi Y. Development of Cereus peruvianus (apple cactus) as a new crop for Negev desert of Israel. In: Janick J, Simon JE. editors. New crops. New York: Wiley, 1993;471-486.
3. Mizrahi Y, Nerd A. Climbing and columnar cacti: new arid lands fruit crops. In: Janick J. editor. Perspective in new crops and new crops uses. Alexandria, ASHS. 1999;358-366.

4. Mizrahi Y. Cereus peruvianus (Koubo) new cactus fruit for the world. Revista Brasileira de Fruticultura. 2014;36(1):68-78.

5. Gutman F, Bar-Zvid D, Nerd A, et al. Molecular typing of C. peruvianus clones and their genetic relationships with other Cereus species evaluated by RAPD analysis. Journal of Horticulture Sciences \& Biotechnology. 2001;76(6):709-713.

6. Silva JGM, Lima GFC, Paz LG, et al. Utilization of native cacti associated with sorghum silage on cattle feeding. Revista Eletronica Cientifica Centauro. 2010a;1:1-9.

7. Cavalcanti NB, Resende GM. Consumo do mandacaru (Cereus jamacaru) por caprinos na época da seca no semi-árido de Pernambuco. Revista Caatinga. 2006;19(4):402-408.

8. Silva JGM, Melo AAS, Rego MMT, et al. Native cacti associated with sabiá and flor de seda shrub hays in dairly goats' feeding. Revista Caatinga. 2011;24(2): 158-164.

9. Silva JGM, Lima GFC, Aguiar EM, et al. Native cacti associated with sabiá and flor de seda shrub hays in male lamb feeding. Revista Caatinga. 2010b; 23(2):123-129.

10. Dutra JCV, Ferreira JM, Pereira PRC, et al. Cereus jamacaru hydroalcoholic extract promotes anti-cytotoxic and antitumor activity. Pharmaceuticals. 2018;11(4):1-18.

11. Assis JGA, Resende SV, Bellintani MC, et al. Plano de ação nacional para a conservação das Cactáceas: Série espécies ameaçadas [National action plan for the conservation of Cacti: Series endangered species]. Icmbio, Brasília, Brazil: Instituto Chico Mendes de Conservação da Biodiversidade. 2011: 44-54.

12. Alvarez M, Costa SC, Huber A, et al. The cuticle of the cactus Cereus peruvianus as a source of a homo-D-galacturonan. Applied Biochemistry and Biotechnology.1995;51/52:367-377.

13. Barros MJ, Nozak J. Pollutants abatement from effluents of paper and pulp industries by flocculation/coagulation and photochemical degradation. Quimica Nova. 2002; 25(5):736-740.

14. Tanaka LYA, Oliveira AJB, Gonçalves JE, et al. An arabinogalactan with anti-ulcer protective effects isolated from Cereus peruvianus. Carbohydrate Polymers. 2010;82(3):714-721.

15. Rego MM, Araújo ER, Rego ER, et al. In vitro seed germination of mandacaru (Cereus jamacaru DC.). Revista Caatinga. 2009; 22(4):3438.

16. Guedes RS, Alvas EU, Gonçalves EP, et al. Germinação de sementes de Cereus jamacaru DC. em diferentes substratos e temperaturas. Acta Scientiarum Biological Sciences. 2009;31(2):159-164.

17. Alencar NLM, Innecco R, Gomes-Filho E, et al. Seed reserve composition and mobilization during germination and early seedling establishment of Cereus jamacaru D.C. ssp. jamacaru (Cactaceae). Annals of Brazilian Academy of Sciences. 2012;84(3):823-832.

18. Beviláqua MRR, Santana Filho AP, Mangolin CA, et al. Genetic and chemical diversity in seeds of cactus mandacaru (Cereus sp.) from two edapho climatic regions contrasting. Annals of Brazilian Academy of Sciences. 2015; 87(2):765-776.

19. Nascimento JPB, Vieira DCM, Meiado MV. Ex situ seed conservation of Brazilian cacti. Gaia Scientia. 2015;9(2):111-116.

20. Meiado MV, Rojas-Aréchiga M, Siqueira-Fillho JA, et al. Effects of light and temperature on seed germination of cacti of Brazilian ecosystems. Plant Species Biology. 2016;31(2):87-97. 
21. Carvalho VM, Mangolin CA, Machado MFPS. Seed germination of the Cereus peruvianus Mill. (Cactaceae) somaclones follows a relatively simple protocol. Seed Sciences and Techonology. 2008;36(3):595-600.

22. R Development Core Team. R: A language and environment for statistical computing. R Foundation for Statistical Computing, Vienna, Austria. 2009

23. Abud HF, Pereira MS, Gonçalves NR, et al. Germination and morphology of fruits, seeds and plants of Cereus jamacaru. Journal of Seed Science. 2013;35(3):310-315.

24. Silva JGM, Melo SSNS, Diniz MCNM, et al. Características morfofisiológicas e produção do mandacaru cultivado em diferentes densidades. Revista Centauro. 2012;3(1):33-43.

25. Rojas-Aréchiga M, Casas A, Vázquez-Yanes C. Seed germination of wild and cultivated Stenocereus stellatus (Cactaceae) from the TehuacánCuicatlán Valley, Central México. Journal of Arid Environments. 2001;49(2):279-287.

26. Pivatto MS, Funes G, Ferreras AE, et al. Seed mass, germination and seedling traits for some central Argentinian cacti. Seed Science Research. 2014;24(24):71-77.

27. Bauk K, Flores J, Ferrero C, et al. Germination characteristics of Gymnocalycium monvillei (Cactaceae) along its entire altitudinal range Botany. 2016
28. Meiado MV, Albuquerque LSC, Rocha EA, et al. Seed germination responses of Cereus jamacaru DC. ssp. jamacaru (Cactaceae) to environmental factors. Plant Species Biology. 2010;25(2):120-128.

29. Correia D, Nascimento EHS, Araújo JDM, et al. Germinação de sementes de cactáceas in vitro. Comunicado Técnico 181. Embrapa Agroindústria Tropical, Fortaleza. 2011.

30. Mihalte L, Sestras RE, Feszt G, et al. Variability of seed traits in interspecific and intergeneric combinations between different genotypes of Cactaceae. Notulae Botanicae Horti Agrobotanici Cluj-Napoca. 2010;38(3):246-252.

31. Faria-Tavares JS, Martin PG, Mangolin CA, et al, Genetic relationships among accessions of mandacaru (Cereus spp.:Cactaceae) using amplified fragment length polymorphisms (AFLP). Biochemical Systematics and Ecology. 2013;48:12-19.

32. Fernandes VNA, Neves AF, Martin PG, et al. Genetic structure and molecular divergence among samples of mandacaru (Cereus spp.; Cactaceae) as revealed by microsatellite markers. Biochemical Systematics and Ecology. 2016;64:38-45. 